\title{
Patentable Subject Matter: Comparison between French and Jordanian Laws
}

\author{
Iriqat Mohammed
}

Alquds University, Main Campus, Abu Dis, P.O Box 89, Palestine

\begin{abstract}
The purpose of this study is to make a comparison between the patentable subject matter in French and Jordanian law in order to extract the similarities and differences to establish basic principles for Palestine. The Jordanian law is selected as it is in general the law that is applied in Palestine.

Palestine is the only country in the Middle East that does not have legislations protecting intellectual property rights. However, there are sporadic laws applied in Palestine, such as the Ottomans' law in 1910 related to copyright law and the Jordanian trademark 1952 and patent law in 1953. In 1995 the Palestinian Authority approved some legislation in the field of private law, such as civil and commercial law, but without including in it intellectual property legislation. The term intellectual property is not popular among Palestinian legislators as there are among them few experts in this field.
\end{abstract}

Keywords: Intellectual property rights, Innovation, Patent, Trips Agreement, Business Method, Discoveries.

\section{INTRODUCTION}

In French law, there is no precise definition of the term invention. In contrast to the Jordanian law which define it in Article 2 as "any invention idea reached by an inventor, in any of the fields of technology, which is related to a product, or a process, or to both which provides a practical solution to a particular problem in any of the said field". (Jordan Patent law, 1999).

The current trend in both legislation French and Jordanian similar to TRIPS agreement confirm that: an invention must meet several criteria if it is to be eligible for patent protection. Firstly the invention must be industrially applicable, then it must be new (novel), and finally it must exhibit a sufficient "inventive step".( Art.27 of Trips agreement, 1995).

Nonetheless, the European Patent Convention and both the French and Jordanian law, excludes the Following classes from its definition of "invention":

- Discoveries, scientific theories and mathematical methods;

- $\quad$ Aesthetic Creations;

- $\quad$ Schemes, Rules and Methods for performing mental acts, playing games or doing business,

- Methods of treatment for humans or animals, or diagnostic methods practiced on humans or animals

*Address correspondence to this author at the Alquds University, Main Campus, Abu Dis, P.O Box 89, Palestine; Tel: +972598346111;

E-mail: marikat@staff.alquds.edu
- $\quad$ Programs for computers; (Article 52 of European patent Convention, 1973)

\section{DISCOVERIES}

Whether in French or in Jordanian law, discoveries have been regarded as outside the scope of patentable subject matter because it does not have the character of a creation.

Regarding Nicolas Bouche (2014): "a discovery consists of establishing a phenomenon which existed in the nature, but was unknown. It is unpatentable as such, but the industrial applications of a discovery may be patented. Whereas what characterizes the invention is that it is voluntary coordination by human material resources (Luc, 2003).

On other words, it's the laws of nature, physical phenomena and abstract ideas. Therefore, discoveries often lead to practical inventions, and those inventions are patentable (Mousseron, 1984).

According to Professor Binctin (2007), this exclusion is due to the fact that "the intellectual effort is not in question, regardless of the difficulties encountered in reaching the discovery, it is always the identification of a natural state and not a creation."(Binctin, 2007). However, if it is a natural substance that is produced by a technical effect, it may be patentable, only for its technical effect.

Any human intervention that allows making the distinction is a measure of patentability (Dulian, 1999). Since this human intervention occurs either at the creation of the product, or that of his application. Thus, the discovery of a natural product can result in patent 
protection (Lamy 2000). However, since the product is not found obviously in nature and its creation involves human intervention, it may be in the presence of a patentable invention. This is particularly the case of the products obtained by fermentation of a microorganism (Vivant, 2005).

The French case law has confirmed the nonpatentability of the discovery by a judgment of the Supreme Court on 7 February 2007. The High Court of Paris in the case "Institut Pasteur $v$ Chiron Blood Testing," stated that; "a virus was not patentable in itself but that all or part of its genome was patentable inasmuch as it enables the manufacture of a product used for diagnosis or treatment" (HCP, Institute Pasteur, 2007).

The ultimate result that the researcher disagree to consider that the discoveries outside the scope of patentable subject matter of the Jordanian and French legislators as well the international agreements should start deeply thinking to protect the discoveries due to its a result of human effort.

\section{AESTHETIC CREATIONS}

Both French and Jordanian laws exclude the scope of patentability in "aesthetic, artistic creations." They are protected may be under the copyright laws if it's origin, e.g. (painting, sculpture, etc). Such exclusions might seem unfortunate at a time when aesthetics develop in the field of manufacture of utilitarian objects. This is because the patent in French law allows ownership of a function, not form. The aesthetic choice of designer is indifferent. However, if the aesthetic form is excluded from patentability, a patent may cover technical means used to obtain this form, or technical structures that create the aesthetic effect. Therefore, we retain complete independency between the means used to achieve aesthetic creations and the result (Binctin, 2007).

The Board of Appeal of the European Patent Office (EPO) summarized this way:

"In T 686/90 the board was called upon to decide whether the feature "work of art in the style of stained glass" meant that it was excluded from patentability under Art. 52(2)(b) EPC 1973. The board held that functional information referring to general aesthetic creations did not define an aesthetic creation as such, at least provided that and insofar as such information adequately identified technical features of the subject-matter of the claim. Since an aesthetic creation (not formally specified) as the stated purpose, together with the other features, adequately defined a technical subject-matter in the claim, there was no aesthetic creation as such. For this reason there could be no objection to the claim under Art. 52(2)(b) EPC 1973 on the basis of Art. 52(3) EP 1973 (EPO, 1973).

\section{SCHEMES, RULES AND BUSINESS METHODS}

French and Jordanian law, scientific theories, and mathematical methods are also excluded from the scope of protection. Furthermore, French law has added another measure of exclusion for "schemes, rules and methods for performing mental acts, playing games, or in doing business." Schemes, rules and methods for performing mental acts have "abstract" and not industrial applications (Becquet, 2005).

A simple idea has never been appropriate. This is a very general rule that also applies in literary and artistic property. One cannot legitimately protect the concrete of an idea, nor the abstract idea accomplishments (Dulian, 1999).

Thus, when the alleged invention solves an economic problem, not a technical, then it is a commercial method is not patentable, unimportant it uses technical means to solve this problem of nontechnical. This is what was decided by the Court of Appeal of Paris in a judgment of 15 March 2006 (PIBD, 2006)

Regarding the business method, Article L.611-10, paragraph 2, 3, (French property code) has confirmed the exclusion of business methods. It stated that: "1. Inventions which are susceptible of industrial application, which are new and which involve an inventive step shall be patentable.2. The following in particular shall not be regarded as inventions within the meaning of the first paragraph of this Article: a) discoveries, scientific theories and mathematical methods; b) aesthetic creations; c) schemes, rules and methods for performing mental acts, playing games or doing business, and programs for computers; ........."

However, in the United States of America, it is possible to grant patents for the "Business Method". 
The Business Method are all methods used in direct contact between a company and its customers as well as any method that allows a business to run, both internally and in its relations with third parties ( WIPO, 2014). We argue that the patentability of business methods was confirmed by US court of appeals in 1998 decision; it stated that "a mathematical algorithm is not excluded from patentability if it produces a useful, concert and tangible result" (CAFC, 1998).

The challenge is to distinguish the method is not a patentable process that is perfectly fine. The criterion is that the abstraction of the first opposed to the industrial character of the second. The method results in an abstract intellectual result as the process leading to an industrial result that materializes in a technical effect or product. This explains why we link exclusion methods to lack of industrial character (Galloux and Azema, 2006).

However, exceptions which appear to diminish the rule exist for both software and business-related inventions, so long as they are seen as addressing technical problems: both the EPO and France make patentability determinations on the basis of "technical contribution" (Dulian, 1999).

In Jordan, Article L.4 patent law also excludes business methods from protection, so that commercial exploitation is useful for the protection of life, human health, animals, or plants to avoid serious environmental damage.

The evidence presented in this research that the Jordanian law restricts the exclusion of Business method in particularly to the issue which makes impact on the life, contrary to French law which keeps it extensively.

\section{COMPUTER PROGRAMS}

In French law, the articles 511-1 and $611-10$ of the Code of Intellectual Property and Article 52 EPC computer programs differ in their scope. Yet, this exclusion appears to contradict Article $27 \S 3$ of TRIPS. Computer programs can be protected through copyright law as stated in Article L112-2, 13 of the Code of Intellectual Property.

Professor Joanna Schmidt (2012) defines a computer program as a set of instructions expressed in a specific form and sent to a computer for a specific result. The software is the product of an intellectual activity expressed in a particular language that responds to the idea of creation of form. Every programmer expresses his personality in how to write the program, making personal choices (Caillaud, 2003).

The reasons for this exclusion are multiple. First, they take the particularism of this kind of creation that lead to technical difficulties in the implementation of patent protection (meeting the requirements of an industrial character, novelty and inventive step above, formulation of claims, appreciation counterfeiting (Dulian, 1999).

Second, difficulties arise relating to the disclosure requirement of the invention. The technique of the patent requires full disclosure of the invention, therefore, to describe the program so that "the art" could reproduce with only basic knowledge. However, the section 611-10.3 of the Code of Intellectual Property shall apply to inventions whose software is only one component. Software are not a patentable, however, a technical invention which involves software is patentable.

The French courts have upheld this rule by a judgment of Court of Appeal of Paris on 15 June 1981: "If computer programs are in principle excluded from patentability, a method may be deprived of patentability for the sole reason that one or more of these steps are performed by a computer to be controlled by a program" (Mathély, 1982).

Regarding the position of the European Patent Office (Lucas, 1990). The EPO case law has confirmed the non-patentability of the software by a judgment of the board of appeal on 5 March 2002 stated that: "information modelling is in principle a non-technical activity, and only a purposive use of information modelling in the context of a solution to a technical problem may contribute to the technical character of an invention.

The Board considers that the claimed connection with CAD/CAM activities cannot qualify as such a purposive technical use. The product data-model does not enable, improve, or otherwise contribute to the solution of a concrete technical problem. The features defining the "product data-model" hence are nontechnical. This means that they cannot contribute to an inventive step. Since the mere additional mention of unspecified CAD/CAM activities and the feature specifying that the product data-model is "stored in a memory associated with a computer" cannot support an inventive step either, the invention as defined by 
claim 1 lacks an inventive step within the meaning of Articles 52(1) and 56 EPC over a notorious general purpose computer. (...) "(EPO, 2014).

Concerning the principle of cumulative protection by both copyright and the industrial property law, excluding the explicit exclusion, this combination should be possible for programs, computers, or software (Binctin, 2007).

Indeed, the EPO and the European Commission wanted to remove the explicit exclusions for the exercise of various intellectual property rights on computer programs. However, this reform has failed twice before the European Parliament (EC, 2014).

The Jordanian patent law does not mention the computer programs in the list of areas enjoying protection. The computer program may like the French law to be protected by copyright filed.

The research suggests that the Jordanian patent law through its upcoming reform should continue protecting computer programs within the scope of copyright. At variance from the United States Law which includes the protection of computer programs within patent law similar to the European Union efforts to apply US patent law. Since protecting computer programs within the scope of copyright enables the author to obtain a longer protection in terms of duration.

\section{METHODS FOR TREATMENT OF THE HUMAN OR ANIMAL BODY BY SURGERY OR THERAPY AND DIAGNOSTIC METHODS}

Methods for treatment of the human or animal body by surgery or therapy and diagnostic methods are not regarded as inventions susceptible of industrial applications (Lestanc, 2009).

Article L611-16 of French intellectual property code and (Art. 53 EPC) provides that "methods for treatment of the human or animal body by surgery or therapy and diagnostic methods practiced on the human or animal body shall not be regarded as inventions susceptible of industrial application within the meaning of Article L611-10. This provision shall not apply to products, in particular substances or compositions, for use in any of these methods." Therefore this exclusion is largely based on public interest, public health and ethical considerations (Galloux, 2006).

The medical procedures cannot be appropriated by the patent; however, the secret can sometimes allow reserving them. Jordanian law, meanwhile, did not address the topic of methods for surgical or therapeutic treatment of the human body. This may be because of the sensitivity of the subject, the Muslim religion; and customs of Jordan considering the human body as sacred.

\section{PLANT VARIETIES}

Patent law in France has been reluctant to host organic or vegetable creations in its protection. Plant varieties eventually become an ad hoc regime defined and organized by the law of 11 June 1970, which created a title specific property: the plant breeders' rights (VOCs).

UPOV (Union for the Protection of New Varieties of Plants) came into force in 1968, as revised at Geneva in 1972, 1978 and 1991, ratified by France on November 10, 1972 , and by Jordan on September 24, 2004. It defines the varieties plant in Article 1, paragraph 6 stated that:

"variety means a plant grouping within a single botanical taxon of the lowest known rank, which grouping, irrespective of whether the conditions for the grant of a breeder's right are fully met, can be

- $\quad$ defined by the expression of the characteristics resulting from a given genotype or combination of genotypes,

- $\quad$ distinguished from any other plant grouping by the expression of at least one of the said characteristics and

- $\quad$ considered as a unit with regard to its suitability for being propagated unchanged; "

Under French law, plant varieties are excluded from patent protection. This exclusion is explained today by specific protection regime established in Article 623-1 of the French intellectual property law:

"For the purposes of this chapter, "new plant variety" shall mean any new plant variety, whether created or discovered which:

1. Is different from similar already known varieties by one characteristic that is important, precise and subject to little fluctuation or by several characteristics the combination of which is such as to give it the status of a new variety;

2. Is homogenous in its characteristics; 
3. Remains stable, that is to say identical with its original definition at the end of each cycle of multiplication".

Regarding the duration of protection, it's twenty five years from its issue. For forest, fruit trees or ornamental vine for as well as perennial forage grasses and legumes, potatoes and inbred lines used for the production of hybrid varieties, the term of protection is thirty years .

Likewise, Jordanian law, like the French excludes from protection patenting plant varieties. The Jordanian Parliament created a new a specific measure in 2000 , "the law of plant breeders", which protecting creations in agriculture field. The plant variety certificate is issued by the Jordanian Ministry of Agriculture in the Plant Variety department.

Regarding the duration of protection, the article 18 of the Jordanian law resembles, with the same rules as in Article L.19 of the UPOV Convention" The said period shall not be shorter than 20 years from the date of the grant of the breeder's right. For trees and vines, the said period shall not be shorter than 25 years from the said date".

The Jordanian law, in Article L.5 posed four conditions necessary to qualify for the protection afforded to plant varieties:

- $\quad$ The novelty;

- The distinctive character, which is that which distinguishes a variety of other varieties of the same species;

- The homogeneity criterion, which is that of a likeness or resemblance between the individuals who compose it, that is to say, the existence of a large number of characteristics common to all plants variety;

- The requirement of stability, which controls a variety for which protection is asked for is stable in its essential character, that is to say, it remains true to its description after repeated propagation or successive.

For foreigners living in France or Jordan, the UPOV Convention provides that all foreigners who's country signs the UPOV Convention, can get a plant variety certificate (VOCs) under the same conditions as French or Jordanian (Article 623-6, of French intellectual property code, 1992).

\section{CONCLUSION}

This research draws principally from the understanding that a patent is a right granted to the owner of an invention, which is a product or a process that provides a new technical solution to a technical problem. Narrowly, the inventions of a technical character are taken into account for patent protection; hence the discoveries, aesthetic creations, business method, methods of treatment for humans or animals, or diagnostic methods practiced on humans or animals, and software are not patentable.

After having made the comparison between the Jordanian and French patent law, the research demonstrates that there are several similarities between both countries, since both systems apply international patent agreements in their national legislative.

The researcher have chosen Jordan as a model to offer a solution for the establishment of an effective legal system for Patent rights in Palestine since the majority of the law and regulations of my country, (Palestine), are based on Jordanian law. The recognition of Palestine on November 29, 2012 as a non-member observer state in the UN allows Palestine to be a member of all United Nations agencies, including the WIPO, to benefit from IP protection at the international level. As consequences the Palestinian legislator should start seriously thinking about creating a Palestinian intellectual property code

\section{REFERENCES}

Abbott F, 2004. "The Doha Declaration on the TRIPS Agreement and Public Health and the Contradictory Trend in Bilateral and Regional Free Trade Agreements", Occasional Paper 14, Quaker United Nations.

Abughet M, 2003. "The legal protection of computer programs". Alad Law Review, 45(3):327-348.

Alnahi E, 2000. "ABC commercial and industrial property". Amman: Dar Alfar.

Azema J, Galloux J, 2006. "Industrial property law“. Paris: Litec.

Barton J, 2000. "Reforming the patent system Science ". Journal Of Law, 13: 287-292.

Bodenhausen G.H.C., 1968. "Guide to the Application of the Paris Convention for the Protection of Industrial Property". United International Bureaux for the Protection of Intellectual Property.

Caillaud B, 2003. "Intellectual property rights in software", London economic school press.

Carl R, 1997. "International dimensions of patent law as it pertains to animal and agricultural biotechnology". Anima Biotechnology, 8:81-89. http://dx.doi.org/10.1080/10495399709525870

Cassier M, 2008. "Patents and public health in France. Pharmaceutical patent law in- the-making at the patent office 
between the two world wars". History and Technology: An International Journal, 24:135-151.

http://dx.doi.org/10.1080/07341510701810930

Delcorde A., 1985. "The protection of inventions". Industrial Property Law Review, 3: 180-195.

Draft Council Regulation on a Community Patent, EU Council document, 2004, http://register.consilium.eu.int/pdf/en/04/ st07/st07119.en04.pdf

Dulian F, 2010. "Industrial property law“. Paris: Dalouz.

European Patent Convention, 1973. https://www.epo.org/lawpractice/legal-texts/epc.html

French intellectual property code, 1992, http://www.wipo.int/wipolex/ en/details.jsp?id=5563

Galloux J, 2006, "industrial property law“. Paris: Dalouz.

Hansen B, 1997."Protecting inventions in chemistry. Commentary on chemical case law under the European Patent Convention and the German Patent Law, "WILEY-VCH,W einheim.

Hjerbe L, 2003.“U.S. Patent and Trademark Office”. Legal Reference Services Quarterly, 22:53-65. http://dx.doi.org/10.1300/J113v22n01 06

Hunt R, 2004. "Patentability, Industry Structure, and Innovation". The Journal of Industrial Economics, 52:401-425. http://dx.doi.org/10.1111/j.0022-1821.2004.00232.x

Jackson B, 2003. "Innovation and intellectual property: The case of genomic patenting". Journal of Policy Analysis and Management, 22:5-25. http://dx.doi.org/10.1002/pam.10093

Kica E \& Groenendijk N, 2011. "The European Patent system: dealing with emerging technologies". Innovation: The European Journal of Social Science Research, 13:85-105. http://dx.doi.org/10.1080/13511610.2011.571405

Korenko G, 2005.“Intellectual Property Protection and Industrial Growth". The Journal of World Intellectual Property, 4:47-75. http://dx.doi.org/10.1111/j.1747-1796.1999.tb00051.x

Lestanc C, 2009. "Exclusions from patentability". JurisClasseur, Industrial property law.
Love J., 2006. "Four Practical Measures to Enhance Access to Medical Technologies", in Negotiating Health. Intellectual Property and Access to Medicines(editors Roffe P., Tansey G., and Vivas-Eugui D.), London: Earthscan.

Luc J, 2003. "Intellectual property law “. Paris: Litec.

Jordan Patent law, 1953. http://www.wipo.int/wipolex/en/profile.jsp? code $=\mathrm{JO}$

Mousseron J, 1984. "patent treaty". Paris:Litec.

Musungu S.F., 2008. "The TRIPS Agreement and Public Health", in Intellectual Property and International Trade: The TRIPS Agreement (editors Correa C. and Yusuf A.), Kluwer Law Journal 14:115-122.

Nicolas B, 2012. "Intellectual property law in France". Sorbonne Legal Journal. 56:232-240.

Quinn E \& Miller K, 2011. “'Understanding Patents”. Legal Reference Services Quarterly, 20:85-110. http://dx.doi.org/10.1300/J113v20n04 04

Samuel B, 2005. "Industrial property law", Paris: L.G.D.J.

Schmidt J, 2010. "Intellectual Property and Competition Law". Intellectual property Law Review 43:245-368

Vaillard S, Lemercier L, 2011. "Limitation of patents in France" Paris: Litec.

UPOV Convention, 1991, International Union for the Protection of New Varieties of Plants http://www.upov.int/upovlex/en/ upov_convention.html

Vivant M, 2005. "Patent law “.Journal of Law, 30: 71-91.

(TRIPS), 1995, Agreement on Trade-Related Aspects of Intellectual Property Rights https://www.wto.org/english/tratop_e/trips_e/ trips_e.htm

Wagner S, 2008. "Business Method Patent in Europe and Their Strategic Use- Evidence from Franking Device Manufactures". Economics of Innovation and New Technology, 17:173-194. http://dx.doi.org/10.1080/10438590600984042

(c) 2015 Iriqat Mohammed; Licensee Lifescience Global.

This is an open access article licensed under the terms of the Creative Commons Attribution Non-Commercial License (http://creativecommons.org/licenses/by-nc/3.0/) which permits unrestricted, non-commercial use, distribution and reproduction in any medium, provided the work is properly cited. 